\title{
Global radiative effects of solid fuel cookstove aerosol emissions
}

\author{
Yaoxian Huang ${ }^{1, \mathrm{a}}$, Nadine Unger ${ }^{2}$, Trude Storelvmo ${ }^{3, \mathrm{~b}}$, Kandice Harper ${ }^{1}$, Yiqi Zheng ${ }^{3}$, and Chris Heyes ${ }^{4}$ \\ ${ }^{1}$ School of Forestry and Environmental Studies, Yale University, New Haven, CT 06511, USA \\ ${ }^{2}$ College of Engineering, Mathematics and Physical Sciences, University of Exeter, Exeter, EX4 4QE, UK \\ ${ }^{3}$ Department of Geology and Geophysics, Yale University, New Haven, CT 06511, USA \\ ${ }^{4}$ International Institute for Applied Systems Analysis, Laxenburg, Austria \\ ${ }^{a}$ now at: Department of Climate and Space Sciences and Engineering, University of Michigan, Ann Arbor, MI 48109, USA \\ ${ }^{b}$ now at: Department of Geosciences, University of Oslo, Oslo, Norway
}

Correspondence: Nadine Unger (n.unger@exeter.ac.uk)

Received: 27 September 2017 - Discussion started: 28 November 2017

Revised: 19 March 2018 - Accepted: 21 March 2018 - Published: 18 April 2018

\begin{abstract}
We apply the NCAR CAM5-Chem global aerosolclimate model to quantify the net global radiative effects of black and organic carbon aerosols from global and Indian solid fuel cookstove emissions for the year 2010. Our assessment accounts for the direct radiative effects, changes to cloud albedo and lifetime (aerosol indirect effect, AIE), impacts on clouds via the vertical temperature profile (semidirect effect, SDE) and changes in the surface albedo of snow and ice (surface albedo effect). In addition, we provide the first estimate of household solid fuel black carbon emission effects on ice clouds. Anthropogenic emissions are from the IIASA GAINS ECLIPSE V5a inventory. A global dataset of black carbon (BC) and organic aerosol (OA) measurements from surface sites and aerosol optical depth (AOD) from AERONET is used to evaluate the model skill. Compared with observations, the model successfully reproduces the spatial patterns of atmospheric BC and OA concentrations, and agrees with measurements to within a factor of 2 . Globally, the simulated AOD agrees well with observations, with a normalized mean bias close to zero. However, the model tends to underestimate AOD over India and China by $\sim 19 \pm 4 \%$ but overestimate it over Africa by $\sim 25 \pm 11 \%$ ( \pm represents modeled temporal standard deviations for $n=$ 5 run years). Without BC serving as ice nuclei (IN), global and Indian solid fuel cookstove aerosol emissions have net global cooling radiative effects of $-141 \pm 4 \mathrm{~mW} \mathrm{~m}^{-2}$ and $-12 \pm 4 \mathrm{~mW} \mathrm{~m}^{-2}$, respectively ( \pm represents modeled temporal standard deviations for $n=5$ run years). The net radiative impacts are dominated by the AIE and SDE mechanisms, which originate from enhanced cloud condensation
\end{abstract}

nuclei concentrations for the formation of liquid and mixedphase clouds, and a suppression of convective transport of water vapor from the lower troposphere to the upper troposphere/lower stratosphere that in turn leads to reduced ice cloud formation. When $\mathrm{BC}$ is allowed to behave as a source of IN, the net global radiative impacts of the global and Indian solid fuel cookstove emissions range from -275 to $+154 \mathrm{~mW} \mathrm{~m}^{-2}$ and -33 to $+24 \mathrm{~mW} \mathrm{~m}^{-2}$, with globally averaged values of $-59 \pm 215$ and $0.3 \pm 29 \mathrm{~mW} \mathrm{~m}^{-2}$, respectively. Here, the uncertainty range is based on sensitivity simulations that alter the maximum freezing efficiency of $\mathrm{BC}$ across a plausible range: $0.01,0.05$ and 0.1 . BC-ice cloud interactions lead to substantial increases in high cloud $(<500 \mathrm{hPa})$ fractions. Thus, the net sign of the impacts of carbonaceous aerosols from solid fuel cookstoves on global climate (warming or cooling) remains ambiguous until improved constraints on BC interactions with mixed-phase and ice clouds are available.

\section{Introduction}

Worldwide 2-3 billion people rely on solid fuels for the majority of their energy needs (Legros et al., 2009). This household biomass combustion includes burning wood fuel, agricultural residues and dung for cooking, heating and lighting. Emissions from household solid fuel combustion include greenhouse gases (carbon dioxide and methane), black carbon (BC), organic carbon (OC), and other trace gases (e.g., nitrogen oxides). Globally, BC from household solid fuel 
emissions accounts for approximately $25 \%$ of the total anthropogenic BC emissions (Bond et al., 2013). Among different types of cookstoves, advanced charcoal stoves show the lowest BC emission factors, followed by simple charcoal, advanced biomass, rocket and simple wood stoves, respectively (Garland et al., 2017). India contains a large concentration of solid-fuel-dependent households: approximately 160 million households use solid fuels for cooking (Venkataraman et al., 2010). In India, residential biofuel combustion represents the dominant energy sector and accounts for over $50 \%$ of the total source of BC and OC emissions (Klimont et al., 2009). India has a long history of unsuccessful stove intervention programs that have sometimes focused on health benefits (Hanbar and Karve, 2002; Kanagawa and Nakata, 2007; Kishore and Ramana, 2002). Despite years of interventions, the vast majority of Indian households still rely on traditional stoves (Legros et al., 2009). The possible scope for global climate co-benefits in future Indian cookstove intervention programs warrants further examination and analysis of this region. BC-rich household solid fuel emission plays an important role in affecting regional air quality (ArcherNicholls et al., 2016; Carter et al., 2016; Liu et al., 2016) and influencing global climate change (Bauer et al., 2010; Butt et al., 2016; Venkataraman et al., 2005). The human health consequences of solid fuel combustion are substantial (ArcherNicholls et al., 2016; Ezzati and Kammen, 2002; Lelieveld et al., 2015). Nearly $9 \%$ of the global burden of disease is attributable to exposure to household air pollution from solid fuels, equivalent to 2.9 million premature deaths and 86 million disability adjusted life years (DALYs) annually (GBD 2015 Risk Factors Collaborators, 2016). Half of the world's population is exposed to indoor air pollution, mainly attributable to solid fuel usage for household cooking and heating (Bonjour et al., 2013; Smith et al., 2014).

Carbonaceous aerosols from solid fuel combustion interact with the Earth's radiation budget directly by absorbing and scattering solar radiation (direct radiative effect, DRE) and indirectly by changing cloud albedo and lifetime (aerosol indirect effect, AIE), modifying the vertical temperature profile (semi-direct effect, SDE) and changing the surface albedo over snow and ice (surface albedo effect, SAE) (Boucher et al., 2013; Chung, 2005; Chylek and Wong, 1995; Ghan, 2013; Ghan et al., 2012; Myhre et al., 2013). Carbonaceous aerosols affect cloud albedo and lifetimes (the AIE) by acting as cloud condensation nuclei (CCN) or ice nuclei (IN), thus modifying cloud properties and changing the top-of-atmosphere (TOA) radiative fluxes (Lohmann, 2002; Lohmann et al., 2000; Penner et al., 1992; Pierce et al., 2007; Spracklen et al., 2011b). The net climatic effect of carbonaceous aerosols from household solid fuel combustion is not well constrained and even the sign is uncertain (Bond et al., 2013). Bauer et al. (2010) estimated that the net global radiative impact of residential biofuel carbonaceous aerosol emissions is $-130 \mathrm{~mW} \mathrm{~m}^{-2}$. Kodros et al. (2015) have estimated that the net DRE of solid fuel aerosol emissions ranges from -20 to $+60 \mathrm{~m} \mathrm{Wm}^{-2}$ and the AIE from -20 to $+10 \mathrm{~m} \mathrm{Wm}^{-2}$, with uncertainties due to assumptions of the aerosol emission masses, size distribution, aerosol optical properties and mixing states. Butt et al. (2016) reported that the net DRE and AIE of aerosols from the residential emission sector (including coal) ranged from -66 to $+21 \mathrm{~mW} \mathrm{~m}^{-2}$ and from -52 to $-16 \mathrm{~mW} \mathrm{~m}^{-2}$, respectively. Their study did not include greenhouse gases. Moreover, neither of the latter two studies consider the aerosol cloud lifetime effect (second indirect effect), SDE and SAE. From the perspective of policy-relevant country-level assessment of the effects of cookstove burning on global climate, Lacey and Henze (2015) revealed that solid fuel cookstove aerosol emissions resulted in global air surface temperature changes ranging from $0.28 \mathrm{~K}$ cooling to $0.16 \mathrm{~K}$ warming; Lacey et al. (2017) further concluded that emissions reductions, including both aerosols and greenhouse gases, from China, India and Ethiopia will have contributed the most to the global surface temperature changes by 2050 .

None of the previous assessments have included BC-ice cloud interactions that can exert a large influence on the atmospheric radiation balance. A recent study by Kulkarni et al. (2016) showed that BC could act as IN, which was also shown by past lab and field findings (Cozic et al., 2008; DeMott et al., 1999; Koehler et al., 2009). With BC as IN, Penner et al. (2009) estimated that the total radiative forcing of anthropogenic and biomass BC emissions was -300 to $-400 \mathrm{~mW} \mathrm{~m}^{-2}$, with IN parameterizations following Liu and Penner (2005) and Kärcher et al. (2006). Gettelman et al. (2012) further concluded that the AIE from BC emissions was $-60 \mathrm{~mW} \mathrm{~m}^{-2}$, with ice nucleation parameterization following Barahona and Nenes (2009). Hence, a re-assessment of the global climate change impacts of carbonaceous aerosol emissions from the solid fuel cookstove sector that newly incorporates BC as IN is urgently needed.

Here, we employ a global aerosol-climate model to quantify the impacts of solid fuel cookstove carbonaceous aerosol emissions globally and from India on global climate change. Section 2 presents the methods, including the evaluation measurement data sets for $\mathrm{BC}$, organic aerosol (OA) and aerosol optical depth (AOD), the model description and experimental design. Section 3 details the results of the model evaluation and the impacts of the global and Indian solid fuel cookstove emissions on the atmospheric radiation budget and global climate. Discussion and summary are provided in Sect. 4.

\section{Methods}

\section{1 $\mathrm{BC}$ and $\mathrm{OC}$ evaluation measurement database}

Ground-based BC observations are from IMPROVE (the Interagency Monitoring of PROtected Visual Environment, http://vista.cira.colostate.edu/Improve/) for the year 2010 
over North America (Malm et al., 1994), EMEP (the European Monitoring and Evaluation Programme, http://ebas. nilu.no) for 2009-2013 over Europe and sporadic measurement campaigns for China and India. Elemental carbon concentrations are measured using thermal optical reflectance (Chow et al., 1993, 2004; EMEP/MSC-W et al., 2014). Our measurement database comprises a total of 152 sites from IMPROVE, 28 sites from EMEP, 35 sites for China and 41 sites for India. The number of urban sites includes 8 from IMPROVE, 5 from EMEP, 17 for China and 23 for India. Here we define urban (including semi-urban) sites as the geographic locations of the measured sites in a city and the others as rural sites.

A global network of aerosol mass spectrometer (AMS) surface measurements for OA for 2000-2008 is used for comparison with model simulations (Spracklen et al., 2011a; Zhang et al., 2007; Zheng et al., 2015). The AMS technique measures hydrocarbon-like OA (HOA), oxygenated OA (OOA) and total OA (HOA + OOA). HOA is a surrogate for primary OA (POA) emitted directly from fossil fuel and biomass burning, while OOA is a surrogate for secondary OA (SOA). In this study, we compare monthly mean total $\mathrm{OA}$ with model-simulated total $\mathrm{OA}(\mathrm{POA}+\mathrm{SOA})$. The majority of the AMS measurements in the surface concentration database were made prior to 2005 .

Ground-based AOD observations from AERONET (AErosol RObtic NETwork, https://aeronet.gsfc.nasa.gov) during 1993-2016 are applied to examine model skill (Dubovikl and King, 2000; Holben et al., 1998, 2001). A climatological AOD value averaged over 1993-2016 for each site is used to compare with the model simulation. The AERONET version 2 level-2 product is used in this study.

\subsection{NCAR CAM5-Chem global model description}

We apply the NCAR Community Atmosphere Model version 5.3 with chemistry (CAM5-Chem) within the Community Earth System Model (CESM) version 1.2.2 (Emmons et al., 2010; Lamarque et al., 2012; Tilmes et al., 2015). The oxidant-aerosol system is fully coupled in CAM5-Chem. The horizontal resolution of CAM5-Chem is $0.9^{\circ}$ latitude by $1.25^{\circ}$ longitude, with 56 vertical levels from the surface up to about $40 \mathrm{~km}$. In the standard CAM5-Chem, aerosol microphysical processes are represented using a three-mode scheme (MAM3; Aitken, accumulation and coarse modes). MAM3 simulates both mass and number concentrations of aerosols. Aerosol size distributions in each mode are assumed to be lognormal (Liu et al., 2012). The model treats the effects of aerosol acting as $\mathrm{CCN}$ in liquid-phase clouds (Ghan et al., 2012). The aerosol components in MAM3 include BC, primary organic matter (POM), secondary organic aerosol (SOA), sulfate, sea salt and dust, which are assumed to be internally mixed within each lognormal mode. Specifically, BC and POM from solid fuel cookstove emissions are treated in the accumulation mode, with a size range of $0.058-$
Table 1. Annual budget for various species for the BASE, GBLSF_OFF and INDSF_OFF simulations for the year 2010.

\begin{tabular}{lrrr}
\hline Species & $\begin{array}{r}\text { ECLIPSE } \\
\text { V5a (BASE)* }\end{array}$ & GBLSF_OFF* & INDSF_OFF* \\
\hline $\mathrm{BC}$ & 7.23 & 4.92 & 6.87 \\
$\mathrm{POM}$ & 18.9 & 8.53 & 17.2 \\
$\mathrm{SO}_{2}$ & 98.5 & 97.1 & 98.37 \\
$\mathrm{NO}_{x}$ & 120.5 & 118 & 119.8 \\
$\mathrm{VOCs}$ & 81.1 & 52.4 & 76.6 \\
$\mathrm{CO}$ & 548 & 358 & 516 \\
$\mathrm{NH}_{3}$ & 54.9 & 54.6 & 54.87 \\
\hline
\end{tabular}

* Units are $\mathrm{Tg}$ species $\mathrm{yr}^{-1}$.

$0.27 \mu \mathrm{m}$ (Liu et al., 2012). Mass yields of semi-volatile organic gas-phase species (SOAG) from emissions of isoprene, monoterpenes, big alkanes and alkenes, as well as toluene, are prescribed (Emmons et al., 2010; Liu et al., 2012; Tilmes et al., 2015). The condensable SOAG reversibly and kinetically partitions into the aerosol phase to form SOA in CAM5Chem as described in Liu et al. (2012).

\subsection{Emissions}

Global anthropogenic emissions are from the IIASA (International Institute for Applied System Analysis) Greenhouse Gas-Air Pollution Interactions and Synergies (GAINS) integrated assessment model ECLIPSE V5a (Evaluating the Climate and Air Quality Impacts of Short-lived Pollutants version 5a) for the year 2010 (Amann et al., 2011, 2013; Klimont et al., 2017; Stohl et al., 2015). Species in ECLIPSE V5a include BC, POM, sulfur dioxide, nitrogen oxides, carbon monoxide, volatile organic compounds and ammonium, with their annual global budgets for the year 2010 shown in Table 1. ECLIPSE V5a emissions available at $0.5^{\circ}$ latitude by $0.5^{\circ}$ longitude spatial resolutions are re-gridded to the model spatial resolution. ECLIPSE V5a does not include shipping or wildfire biomass burning emissions, which are instead obtained from the IPCC AR5 RCP8.5 scenario for the year 2010 (Riahi et al., 2011).

\subsection{Simulations: BC not active as IN}

Atmosphere-only simulations are performed in specified dynamics mode with offline meteorological fields from the Goddard Earth Observing System model version 5 (GEOS5). In this specified dynamics mode configuration, the internally derived meteorological fields (e.g., horizontal wind component, air temperature and latent heat flux) are nudged by $10 \%$ towards reanalysis fields from GEOS-5 for every model time step. The nudging technique in CAM5-Chem has been evaluated to quantify the aerosol indirect effect in order to reduce the influence of natural variability (Kooperman et al., 2012). Sea surface temperature and sea ice in 
Table 2. Model experiments' setup.

\begin{tabular}{ll}
\hline Experiments & Anthropogenic emission scenario \\
\hline BASE & ECLIPSE V5a \\
GBLSF_OFF & $\begin{array}{l}\text { ECLIPSE V5a excluding global } \\
\text { solid fuel cookstove emissions }\end{array}$ \\
INDSF_OFF & $\begin{array}{l}\text { ECLIPSE V5a excluding Indian } \\
\text { solid fuel cookstove emissions }\end{array}$ \\
\hline
\end{tabular}

the model are prescribed from the Climatological/Slab Ocean Data Model (DOCN) and Climatological Ice Model (DICE), respectively, with monthly varying decadal mean averaged over 1981-2010.

We perform three sets of model simulations using the model configurations shown in Table 2. The first set of simulations represents the control with anthropogenic emissions following ECLIPSE V5a, as described above (hereafter referred to as BASE). The second set of simulations are identical to the BASE simulation except the global solid fuel cookstove emissions for aerosols and gas-phase aerosol, and ozone precursors are set to zero (termed as GBLSF_OFF). The third set of simulations is identical to BASE except the solid fuel cookstove emissions are set to zero over the Indian subcontinent (termed as INDSF_OFF). We run all the above simulations for 6 years from 2005 to 2010, with the first year discarded as spin-up and the last 5 years averaged for output analysis. The differences between BASE and GBLSF_OFF isolate the impacts of the global solid fuel cookstove sector aerosol emissions, and the differences between BASE and INDSF_OFF isolate the impacts of the Indian solid fuel cookstove sector aerosol emissions. TOA aerosol shortwave (SW) and longwave (LW) radiative effects are calculated using the Rapid Radiative Transfer Model for general circulation models that is coupled to CAM5-Chem (Ghan, 2013; Ghan et al., 2012).

\subsection{Simulations: BC active as IN}

In default CAM5-Chem, BC is not treated as IN (Liu et al., 2012; Tilmes et al., 2015). IN concentrations from homogeneous nucleation are calculated as a function of vertical velocity (Liu et al., 2007). Several lab and field studies indicate that BC particles can act as IN (Cozic et al., 2008; DeMott et al., 1999; Koehler et al., 2009; Kulkarni et al., 2016). Therefore, we conduct additional simulations that treat $\mathrm{BC}$ as effective IN applying the ice nucleation scheme of Barahona and Nenes (2008, 2009). The scheme estimates maximum supersaturation and ice crystal concentrations and considers competition between homogeneous and heterogeneous freezing. Homogeneous nucleation occurs in solution droplets formed on soluble aerosols (mainly sulfate), while heterogeneous nucleation occurs on IN, which here are a small subset of mineral dust and black carbon particles. The
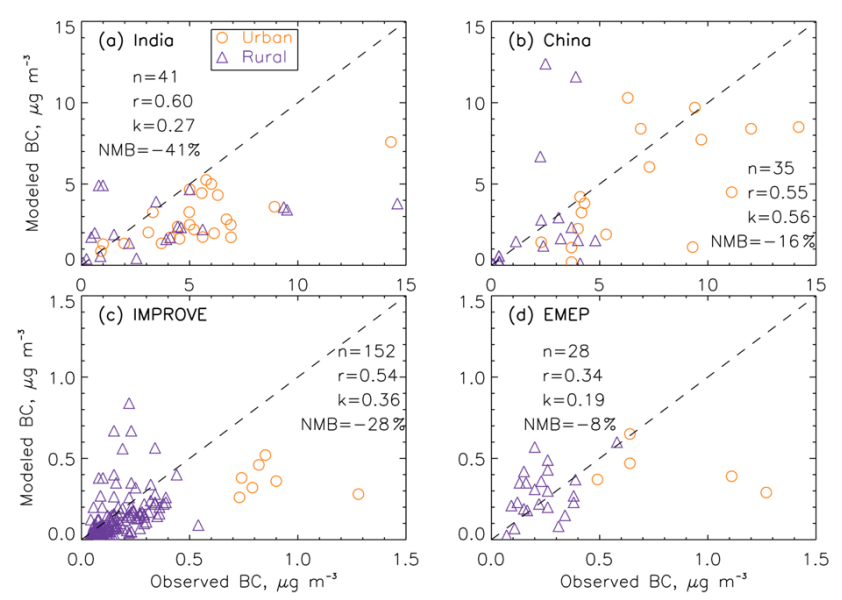

Figure 1. Comparisons of observational and model-simulated annual mean surface BC concentrations from (a) India, (b) China, (c) IMPROVE and (d) EMEP. Urban and rural sites are shown by orange circles and blue triangles for each region. For each panel, the total number of observational sites $(n)$, model-observation regression slopes $(k)$, correlation coefficient $(r)$ and NMB values are included. The dashed line in each panel represents the $1: 1$ ratio.

heterogeneous freezing of $\mathrm{BC}$ and dust is described as a generalized ice nucleation spectrum.

We perform three additional model simulations, with model configurations identical to those in Table 2, except for the treatment of BC particles as effective IN. In addition, for each model simulation, we alter the plausible maximum freezing efficiency (MFE) of BC to be 0.01, 0.05 and 0.1 , which provides an uncertainty range in the global climatic impact assessment.

\section{Results}

\subsection{Evaluation of surface $\mathrm{BC}$ and $\mathrm{OA}$ concentrations}

Surface observation networks from IMPROVE, EMEP and various campaigns in China and India are employed for comparison with model simulations, as shown in Fig. 1. We diagnose the normalized mean bias (NMB) for each source region, calculated as

$\mathrm{NMB}=\left(\frac{\sum_{i}\left(M_{i}-O_{i}\right)}{\sum_{i} O_{i}}\right) \times 100 \%$,

where $M$ and $O$ represent monthly mean model-simulated and observational concentrations at site $i$, respectively, and $\sum$ is the sum over all the sites within a source region.

In general, the model-simulated surface $\mathrm{BC}$ concentrations agree with observations to within a factor of 2 , consistent with previous studies (Huang et al., 2013; Wang et al., 2011, $2014 a, b)$. A total of 41 surface BC observational sites are used to evaluate the model simulation over India (Fig. 1a). 

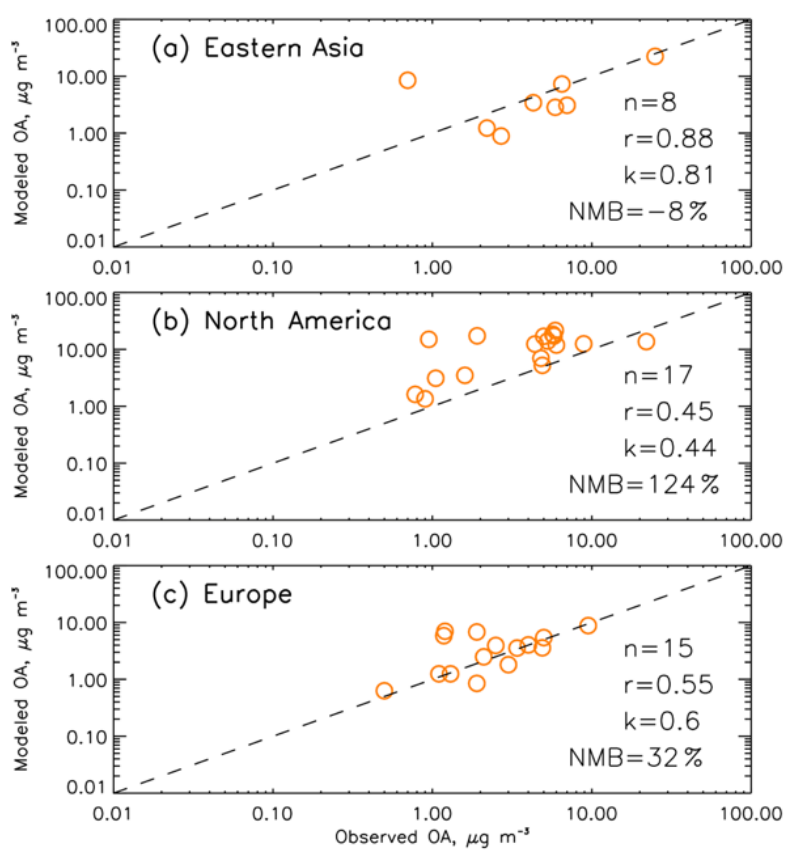

Figure 2. Comparisons of observational and model-simulated surface OA concentrations from (a) eastern Asia, (b) North America and (c) Europe. For each panel, the total number of observational sites $(n)$, model-observation regression slopes $(k)$, correlation coefficient $(r)$ and NMB values are included. The dashed line in each panel represents the $1: 1$ ratio.

On average, the model underestimates surface BC concentrations by approximately 45 and $34 \%$ over urban and rural sites, respectively, with a total NMB of $-41 \%$ (Fig. 1a), which implies a marked underestimation of the $\mathrm{BC}$ emissions in India. Previous modeling studies have also reported large underestimates of BC surface concentrations over India against observations (Gadhavi et al., 2015; He et al., 2014; Zhang et al., 2015). Part of the model/measurement discrepancy is related to a sampling bias because the majority of the observations are located over urban or heavily polluted regions. For China sites, the NMB value is $-16 \%$ (Fig. 1b). Similar to India, the model substantially underestimates the surface BC concentrations over urban sites with a NMB of $-30 \%$. However, the model performs relatively well over rural areas, with a NMB close to zero. For IMPROVE, the NMB values for rural and urban sites are -15 and $-43 \%$, respectively, with a total NMB of $-28 \%$ (Fig. 1c). Over Europe, the model-simulated surface $\mathrm{BC}$ concentrations agree quite well with observations, with a NMB value of $-8 \%$, although two urban sites show substantial model underestimation (Fig. 1d).

The 40 AMS surface OA measurements are grouped into three categories: eastern Asia (8 sites), North America (17 sites) and Europe (15 sites) (Spracklen et al., 2011a; Zhang et al., 2007; Zheng et al., 2015). Figure 2 shows the evaluation of simulated surface OA against observations. Over eastern
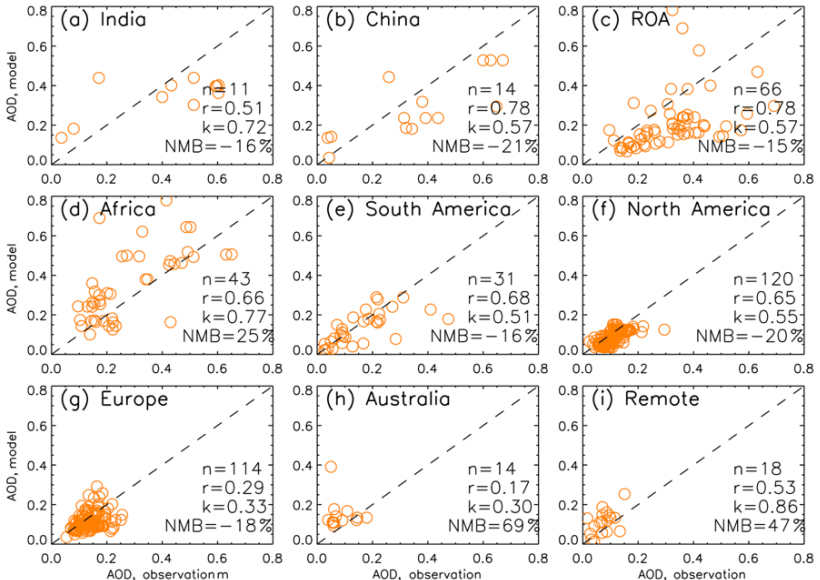

Figure 3. Scatter plots of AOD between model simulation and observations over (a) India, (b) China, (c) rest of Asia (ROA), excluding China and India, (d) Africa, (e) South America, (f) North America, (g) Europe, (h) Australia and (i) remote regions. For each panel, the total number of observational sites $(n)$, model-observation regression slopes $(k)$, correlation coefficient $(r)$ and NMB are included.

Asia, the model slightly underestimates observed OA, with a NMB of $-8.5 \pm 5 \%$ ( \pm represents modeled temporal standard deviations for $n=5$ run years) (Fig. 2a). In contrast, the simulated OA concentrations overestimate the measurements by over a factor of 2 in North America, with a NMB value of $124 \pm 24 \%$ (Fig. 2b). For the European sites, we find a simulated OA overestimation of measured concentrations by up to $0.9 \pm 0.7 \mu \mathrm{g} \mathrm{m}^{-3}$, corresponding to a NMB of $+32 \pm 26 \%$ (Fig. 2c).

\subsection{Evaluation of model AOD}

Figure 3 compares simulated AOD values against observations over nine regions across the globe, including India, China, rest of Asia (excluding China and India), Africa, South America, North America, Europe, Australia and remote regions. Over India, the simulated annual mean AOD is lower than observations by about $16 \pm 3 \%$ (Fig. 3a), with large bias sources mainly from the northern India regions (e.g., New Delhi and Kanpur). This is consistent with Quennehen et al. (2016), who also reported that model-simulated AOD values were generally lower than satellite-derived AOD over northern India, using the same emission inventory as our study. As discussed in Sect. 3.1, model-simulated surface $\mathrm{BC}$ concentrations over India are also underestimated (by up to $41 \%$ ); therefore, the low bias of model-simulated AOD can be attributed, in part, to the underestimation of Indian BC emissions from ECLIPSE V5a emission inventory (Stohl et al., 2015), although global anthropogenic BC budgets in ECLIPSE V5a lie in the high end compared with previous studies (Bond et al., 2004, 2013; Janssens-Maenhout et al., 2015). The model underestimate of AOD from AERONET 
(a) Control zonal mean BC

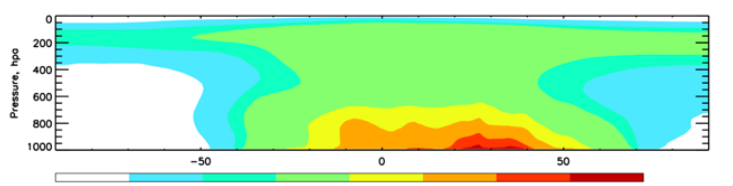

$\left.\begin{array}{llllllllll}0.000 & 0.001 & 0.005 & 0.010 & 0.050 & 0.100 & 0.200 & 0.300 & 0.400 & {\left[\mu \mathrm{g} \mathrm{m}^{-3}\right.}\end{array}\right]$

(b) Global solid fuel zonal mean BC

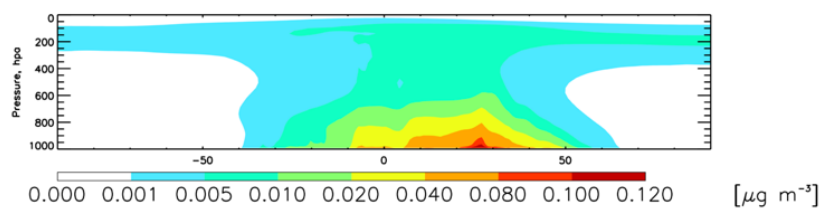

(c) India solid fuel zonal mean BC

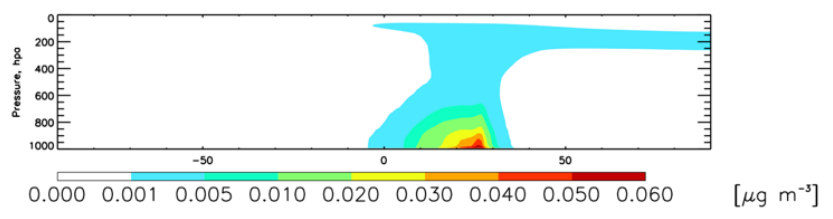

Figure 4. Annual zonal mean BC concentrations from (a) the BASE simulation, (b) the global solid fuel cookstove emissions and (c) India solid fuel cookstove emissions. BC concentrations are calculated under standard temperature and pressure conditions $(273 \mathrm{~K}$, $1 \mathrm{~atm})$.

in India may also be related to the fairly coarse global model resolution, as previously reported by Pan et al. (2015) and Zhang et al. (2015). A similar pattern is found over China (Fig. 3b) and the rest of Asia (Fig. 3c), with NMB values of $-21 \pm 4$ and $-15 \pm 6 \%$, respectively. Model-simulated AOD values from several sites in western Asia (Fig. 3c) are higher than observations, which is probably caused by the model overestimation of dust emissions (He and Zhang, 2014). This directly leads to annual mean model-simulated AOD values over Africa $25 \pm 11 \%$ higher than observations because Saharan dust emissions dominate the AOD over northern Africa (Fig. 3d). For South America, the model generally agrees quite well with observations (Fig. 3e), except for a few sites where model-simulated AOD values are lower than observations by more than a factor of 2 . This is probably due to the model underestimation of biomass burning emissions there (Reddington et al., 2016). AOD values over North America (Fig. 3f) and Europe (Fig. 3g) are relatively lower (with values generally $<0.3$ ), due to lower anthropogenic emissions. In these two regions, modeled AOD agrees with observations within a factor of 2, with NMB values of $-20 \pm 4 \%$ and $-18 \pm 9 \%$, respectively. CAM5Chem overestimates AOD over Australia (Fig. 3h) and remote sites (Fig. 3i), with NMB values of $+69 \pm 17$ and $+47 \pm 12 \%$, respectively. Globally, model-simulated AOD agrees quite well with observations, with $\mathrm{NMB}$ values close to zero.

\subsection{Contribution of solid fuel cookstove sector emissions to atmospheric BC and POM}

\subsubsection{BC}

Annual BC emissions and budgets are reported in Table 3 based on the anthropogenic inventory from ECLIPSE V5a. Annual BC emissions from the global and Indian solid fuel cookstove emissions are 2.31 and $0.36 \mathrm{Tg} \mathrm{yr}^{-1}$, accounting for 23.7 and $3.7 \%$ of the total $\mathrm{BC}$ emissions. For the control simulation, global annual mean $\mathrm{BC}$ burden and lifetime are $0.12 \pm 0.001 \mathrm{Tg}$ and $4.5 \pm 0.04$ days, respectively (Table 3), at the low end of the range estimated by AeroCom (Schulz et al., 2006; Textor et al., 2006).

Figure 4 shows the zonal mean BC concentrations from the control simulation (Fig. 4a), global solid fuel cookstove emissions (Fig. 4b) and Indian (Fig. 4c) solid fuel cookstove emissions, respectively. For the control simulation, in general, the highest $\mathrm{BC}$ concentrations (by up to $0.40 \mu \mathrm{g} \mathrm{m}^{-3}$ ) occur at the surface over the emission source regions in the midlatitudes (e.g., China and India). In the tropics and midlatitudes, zonal mean BC concentrations decrease with increasing altitude, due to wet removal and deposition, as found in Huang et al. (2013). A similar vertical distribution is observed for the impacts from global and Indian solid fuel cookstove emissions, although the magnitude is smaller, compared with the control simulation. Annual mean BC burdens from global and Indian solid fuel cookstove emissions account for about $24.2 \pm 0.7$ and $5.0 \pm 0.0 \%$ of that in the control simulation $(0.12 \pm 0.001 \mathrm{Tg})$.

\subsubsection{POM}

Global POM emissions are mainly from biomass burning (31 $\mathrm{Tg} \mathrm{yr}^{-1}$ ) and anthropogenic emissions (18.9 $\mathrm{Tg} \mathrm{yr}^{-1}$ ), with global and Indian solid fuel cookstove emissions accounting for 21 and $3.4 \%$, respectively, of the total POM emissions (Table 3). In our control simulation, the annual mean POM burden is $0.66 \pm 0.006 \mathrm{Tg}$, and the global annual mean POM lifetime is $4.8 \pm 0.04$ days (Table 3 ).

In Fig. 5, we show the annual zonal mean POM concentrations for the control simulation (Fig. 5a) and for global (Fig. 5b) and Indian (Fig. 5c) solid fuel cookstove emissions. There are two maxima in the annual zonal mean POM concentrations near the surface. One is located in the tropics due to the large biomass burning emissions there, and the other is located over mid-latitude regions and originates mainly from anthropogenic emissions (Chung and Seinfeld, 2002; Huang et al., 2013). For POM concentrations from global solid fuel cookstove emissions, a single maximum is evident in the Northern Hemisphere (NH) subtropics at the surface (Fig. 5b). The surface value for the Indian solid fuel cookstove emissions reaches a maximum in the NH subtropics. The annual mean POM burdens from global and 
Table 3. Global budgets, burden and lifetime of BC and POM from model control simulations.

\begin{tabular}{|c|c|c|}
\hline Species & $\mathrm{BC}$ & POM \\
\hline Sources $\left(\mathrm{Tg}\right.$ species $\left.\mathrm{yr}^{-1}\right)$ & 9.73 & 49.9 \\
\hline Fossil fuel and biofuel emissions & 7.23 & 18.9 \\
\hline Biomass burning emissions & 2.5 & 31 \\
\hline Sinks $\left(\mathrm{Tg}\right.$ species $\left.\mathrm{yr}^{-1}\right)$ & 9.72 & 49.8 \\
\hline Dry deposition & 1.8 & 8.14 \\
\hline Wet deposition & 7.92 & 41.7 \\
\hline Burden $(\mathrm{Tg})^{*}$ & $0.12 \pm 0.001$ & $0.66 \pm 0.006$ \\
\hline Lifetime (days) ${ }^{*}$ & $4.5 \pm 0.04$ & $4.8 \pm 0.04$ \\
\hline
\end{tabular}

* Standard deviation represents the uncertainty error owing to temporal variability in the model.

(a) Control zonal mean POM

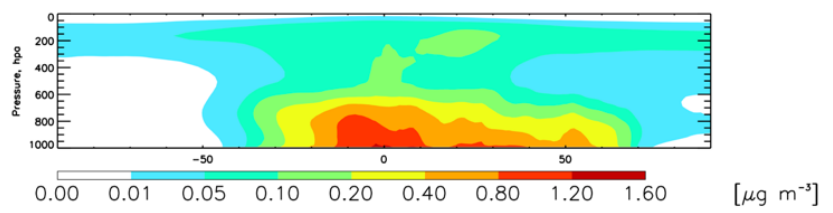

(b) Global solid fuel zonal mean POM

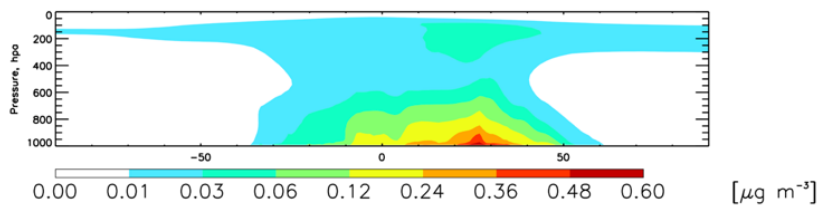

(c) India solid fuel zonal mean POM

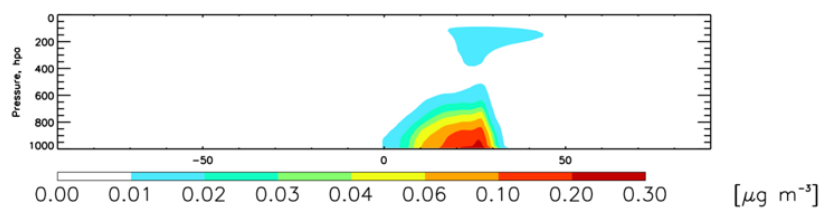

Figure 5. Same as Fig. 4 but for POM.

Indian solid fuel cookstove emissions are $0.13 \pm 0.004$ and $0.027 \pm 0.002 \mathrm{Tg}$, respectively.

\subsection{Impacts of solid fuel cookstove aerosol emissions on global radiation budget}

\subsubsection{Direct radiative effect (DRE)}

The DRE impacts of the global and Indian solid fuel cookstove emissions are shown in Fig. 6. For the global solid fuel cookstove sector, the globally averaged DRE from aerosol emissions is $+70 \pm 3 \mathrm{~mW} \mathrm{~m}^{-2}$ ( \pm represents modeled temporal standard deviations for $n=5$ run years) without treating $\mathrm{BC}$ as IN, which is a warming effect. The positive DRE from global solid fuel cookstove emissions shows large spatial variability, with the largest impacts located over western Africa, followed by India and China (figure not

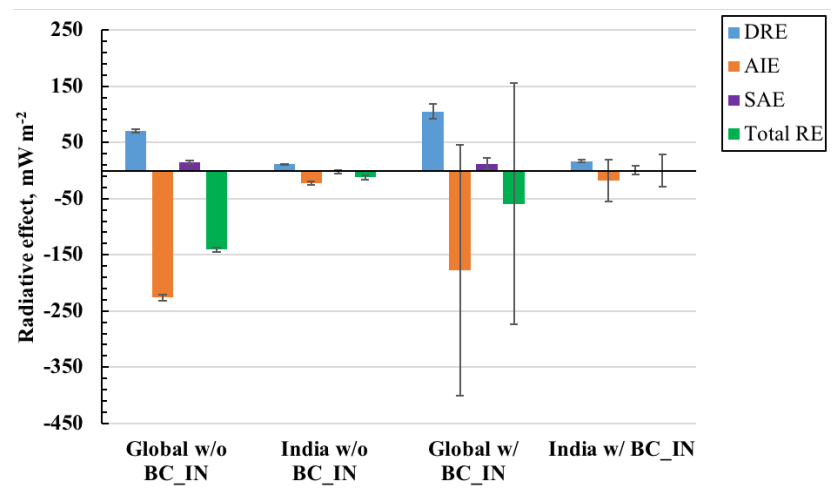

Figure 6. Radiative effect (RE) for global and Indian solid fuel cookstove aerosol emissions with $\mathrm{BC}$ not serving as IN (w/o BC_IN) and BC as IN (BC_IN), with DRE (blue), AIE (orange), SAE (purple) and total RE (green). Error bars represent one standard deviation for each RE. For BC as IN, standard deviations of $\mathrm{RE}$ are solely based on the choices of maximum freezing efficiency of $\mathrm{BC}$ as $0.01,0.05$ and 0.1 , respectively. shown). The contributions of BC and POM to DRE are $+105 \pm 4 \mathrm{~mW} \mathrm{~m}^{-2}$ (warming) and $-14 \pm 1 \mathrm{~mW} \mathrm{~m}^{-2}$ (cooling), respectively. In other words, the warming effect of $\mathrm{BC}$ is partially offset by the cooling effect from POM. Additional cooling effects may come from sulfate and SOA. CAM5-Chem assumes that BC is internally mixed with other components in the accumulation mode and simulates enhanced absorption (the $\mathrm{BC}$ mass absorption cross section is $14.6 \mathrm{~m}^{2} \mathrm{~g}^{-1}$ ) when $\mathrm{BC}$ is coated by soluble aerosol components and water vapor (Ghan et al., 2012), which results in larger estimates of the DRE than for BC alone (Bond et al., 2013; Jacobson, 2001b).

The DRE from Indian solid fuel cookstove emissions also corresponds to a net warming effect (Fig. 6), with a global annual mean value of $+11 \pm 1 \mathrm{~mW} \mathrm{~m}^{-2}$. Large impacts are found over continental India, the Tibetan Plateau and southeastern China. On a global annual basis, DRE values from 


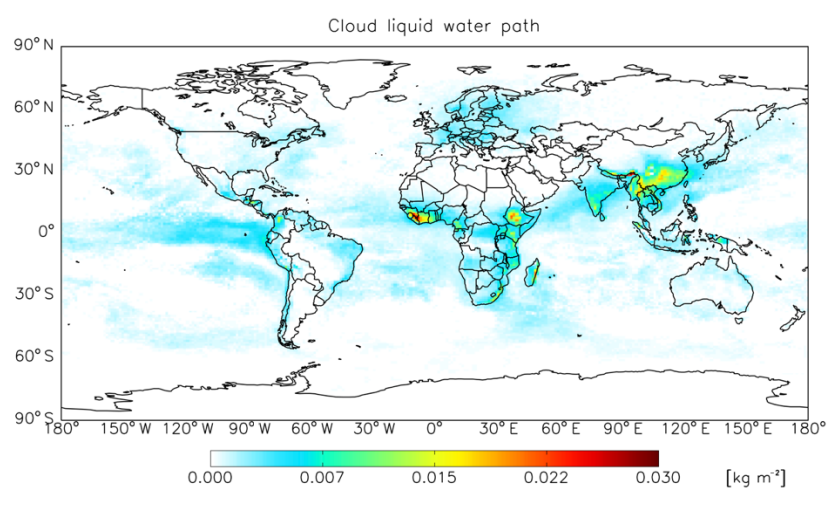

Figure 7. Global vertically integrated cloud liquid water path from the global solid fuel cookstove emissions.

$\mathrm{BC}$ and POM emissions from the Indian solid fuel cookstove sector are $+18 \pm 1$ and $-3 \pm 0.2 \mathrm{~mW} \mathrm{~m}^{-2}$, respectively.

\subsubsection{Aerosol indirect, semi-direct and surface albedo effects: BC not active as IN}

Global annual mean AIE and SAE values from global and Indian solid fuel cookstove aerosol emissions are shown in Fig. 6. In our study, AIE includes the first (albedo) and second (lifetime) indirect effects, as well as the semi-direct effect. The annually averaged AIE from the global solid fuel cookstove sector is $-226 \pm 5 \mathrm{~mW} \mathrm{~m}^{-2}$ (Fig. 6), with an annual mean SW AIE of $-122 \pm 22 \mathrm{~mW} \mathrm{~m}^{-2}$ and a LW AIE of $-104 \pm 17 \mathrm{~mW} \mathrm{~m}^{-2}$, without treating BC as IN. Both the annual mean SW and LW AIE thus yield cooling effects. The cooling signals of SW AIE mainly occur over the western coast of South America, west and east coasts of Africa, southern China and Himalayan regions (figure not shown). This is directly linked to the contribution of global solid fuel cookstove aerosol emissions to CCN (Pierce et al., 2007), which increases the cloud droplet number concentration (CDNC) and cloud liquid water path (CLWP). Figure 7 shows the global vertically integrated distribution of CLWP from the contribution of global solid fuel cookstove aerosol emissions. The higher CLWP is due to the enhanced lifetime of liquid and mixed-phase clouds, which therefore reflect more solar radiation, leading to a cooling effect. For the LW AIE, the largest cooling effect is found over tropical regions, especially over southern India and the Indian Ocean. In order to investigate the causes of the LW AIE cooling effect, we analyze the cloud fraction change over a defined region (latitude: $0-20^{\circ} \mathrm{N}$; longitude: $60-90^{\circ} \mathrm{E}$ ) due to the effect from the global solid fuel cookstove sector. As shown in Fig. 8a, the cloud fraction in the lower troposphere increases. However, in the middle and upper troposphere cloud fraction decreases by up to $0.6 \%$, with the strongest decrease found at $\sim 150 \mathrm{hPa}$. We further analyze the changes in shallow and deep convective mass fluxes of moisture over the same domain. As shown in Fig. 8b, the moist shallow convective mass flux generally shows increases in the lower troposphere, which means that solid fuel cookstove aerosol emissions enhance the convective transport of water vapor within the boundary layer. By contrast, the deep convective mass flux demonstrates decreases from the surface up to the middle troposphere (Fig. 8c). This indicates that solid fuel cookstove aerosol emissions may stabilize the boundary layer and inhibit the transport of water vapor from the surface to the upper troposphere and lower stratosphere (UTLS) region, which leads to decreases in ice cloud formation, thus reducing cloud cover in the UTLS region at around $200 \mathrm{hPa}$ (Fig. 8a) and a LW AIE cooling effect.

The global annual mean AIE from Indian solid fuel cookstove aerosol emissions accounts for approximately $10 \%$ $\left(-22 \pm 3 \mathrm{~mW} \mathrm{~m}^{-2}\right)$ relative to the value of AIE from the global solid fuel cookstove sector (Fig. 6), with globally averaged SW and LW AIE values of $-3 \pm 11$ and $-19 \pm 11 \mathrm{~mW} \mathrm{~m}^{-2}$ respectively.

Global annual mean SAE values from global and Indian solid fuel cookstove sector are relatively small: $+15 \pm 3$ and $-2 \pm 3 \mathrm{~mW} \mathrm{~m}^{-2}$, respectively (Fig. 6). The warming effect is mainly due to the deposition of $\mathrm{BC}$ on the surface of snow and sea ice (Flanner et al., 2007; Ghan, 2013; Ghan et al., 2012).

\subsubsection{Total radiative effect: BC not active as IN}

The net total radiative effects of global and Indian solid fuel cookstove aerosol emissions are both cooling, with the global annual mean estimated to be $-141 \pm 4$ and $-12 \pm 4 \mathrm{~mW} \mathrm{~m}^{-2}$, respectively (Fig. 6). This suggests that if we remove solid fuel cookstove aerosol emissions, it will result in warming and thus slightly increased global surface air temperature. That being said, this is likely to be quite sensitive to the model representation of the aerosol mixing state (Fierce et al., 2017).

\subsubsection{Total radiative effect: BC active as IN}

For the radiative effect of global solid fuel cookstove emissions with $\mathrm{BC}$ as IN, global annual mean DRE is $105 \pm 13 \mathrm{~mW} \mathrm{~m}^{-2}$ ( \pm represents standard deviations from modeling results with BC MFE values of $0.01,0.05$ and 0.1 ), ranging from +90 to $+115 \mathrm{~mW} \mathrm{~m}^{-2}$, which is $29-$ $64 \%$ higher than the DRE values from the default scheme (Fig. 6). Intriguingly, a large globally averaged negative SW AIE $\left(-1.36 \pm 0.63 \mathrm{~W} \mathrm{~m}^{-2}\right)$ and a positive $\mathrm{LW}$ AIE $\left(+1.18 \pm 0.44 \mathrm{~W} \mathrm{~m}^{-2}\right)$ for global solid fuel cookstove aerosol emissions are found, with annual mean values for the SW AIE ranging from -1.83 to $-0.64 \mathrm{~W} \mathrm{~m}^{-2}$ and from +0.67 to $+1.45 \mathrm{~W} \mathrm{~m}^{-2}$ for the LW AIE. This results in a rather uncertain net AIE, with a global annual mean AIE of $-177 \pm 223 \mathrm{~mW} \mathrm{~m}^{-2}$ (Fig. 6). The reason for the large global annual average negative SW AIE and positive LW AIE is a substantial increase in high cloud $(<500 \mathrm{hPa})$ frac- 

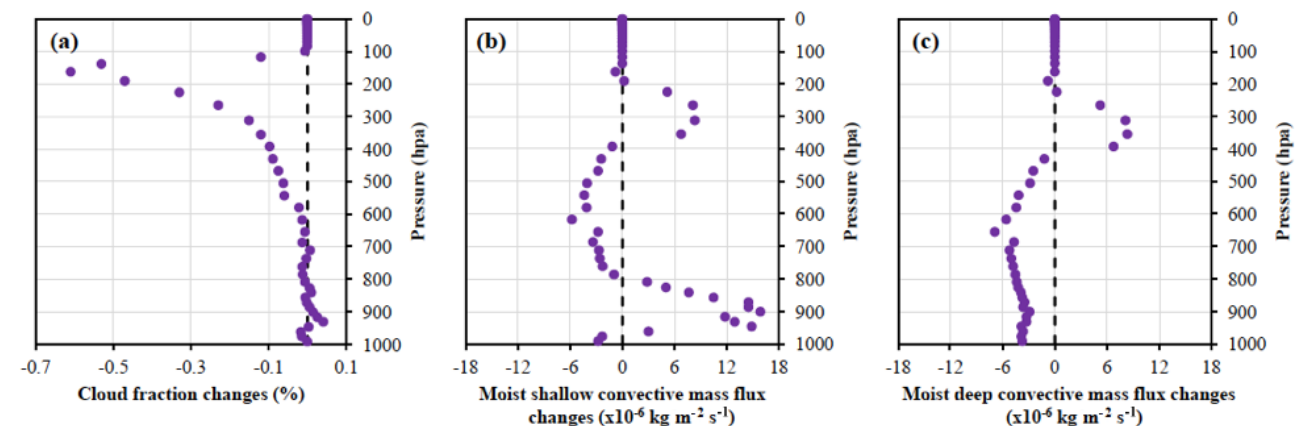

Figure 8. Changes in vertical cloud fractions (a), shallow convective mass flux (b) and deep convective mass flux (c) within the India and Indian Ocean domain from global solid fuel cookstove emissions.

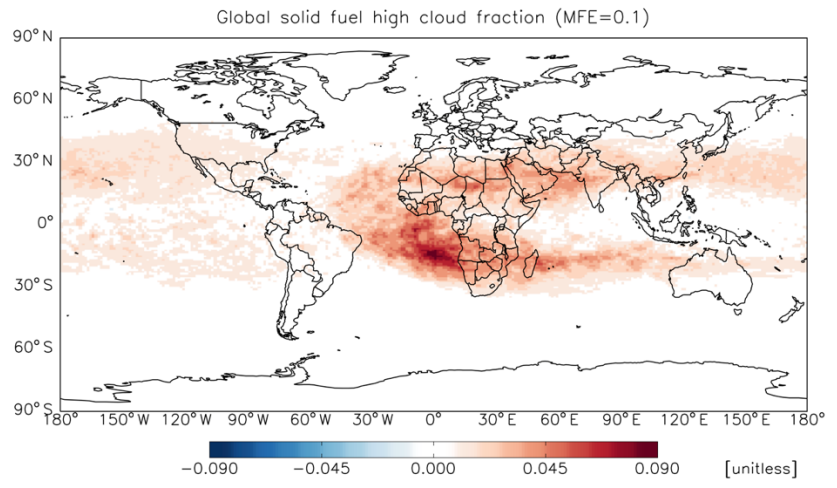

Figure 9. Global distribution of high cloud fraction due to solid fuel cookstove aerosol emissions with $\mathrm{BC}$ as IN and MFE $=0.1$.

tions when BC acts as efficient IN. For instance, with a MFE of 0.1 , large increases (by up to $9 \%$ ) in high cloud fractions from global solid fuel cookstove aerosol emissions are found over subtropical regions, especially over the southern Atlantic Ocean (Fig. 9). With BC particles active as IN, ice particle sizes become smaller, leading to a slower settling velocity for ice particles and thus an increase in the lifetime of ice clouds. Increases in high clouds not only reflect more solar radiation back to space, but also trap more LW radiation within the troposphere. For the SAE, the global annual mean value is $+12 \pm 10 \mathrm{~mW} \mathrm{~m}^{-2}$ (Fig. 6). As a result, the net total radiative effect of global solid fuel cookstove aerosol emissions ranges from -275 to $+154 \mathrm{~mW} \mathrm{~m}^{-2}$, with a global annual mean of $-59 \pm 215 \mathrm{~mW} \mathrm{~m}^{-2}$ (Fig. 6). Again, the source of the large uncertainty of the total radiative effect is due to the choice of MFE values. With MFE $=0.01$, the global mean LW AIE $\left(+672 \mathrm{~mW} \mathrm{~m}^{-2}\right)$ outweighs SW AIE $\left(-638 \mathrm{~mW} \mathrm{~m}^{-2}\right)$ and therefore results in a net warming effect. For other MFE values ( 0.05 and 0.1 ), the absolute global annual mean SW AIE values are always higher than the LW AIE, leading to a net negative (i.e., cooling) total radiative effect.
For the Indian solid fuel cookstove sector, the global annual mean net total radiative effect is $0.3 \pm 29 \mathrm{~mW} \mathrm{~m}^{-2}$, with an AIE of $-18 \pm 37$ and a SAE of $+1 \pm 8 \mathrm{~mW} \mathrm{~m}^{-2}$, respectively.

\section{Discussion and summary}

In this study, we employ the atmospheric component of a global 3-D climate model CESM v1.2.2, CAM5.3-Chem, to investigate the impacts of solid fuel cookstove emissions on global climate change. We update the default anthropogenic emission inventory using IIASA ECLIPSE V5a for the year 2010. We focus our analysis on the radiative effects of global and Indian solid fuel cookstove aerosol emissions. Model performance is evaluated against a global dataset of $\mathrm{BC}$ and $\mathrm{OA}$ measurements from surface sites and AOD from AERONET. Compared with observations, the model successfully reproduces the spatial patterns of atmospheric BC and $\mathrm{OA}$ concentrations, and generally agrees with measurements to within a factor of 2. Globally, the simulated AOD agrees quite well with observations, with NMB values close to zero. Nevertheless, the model tends to underestimate AOD values over source regions (except for Africa) and overestimate AOD over remote regions. The underestimates of AOD over India and China indicate that anthropogenic emissions of carbonaceous aerosols and sulfate precursors in ECLIPSE V5a are underestimated because carbonaceous aerosols and sulfate account for over $60 \%$ of the AOD over these two countries (Lu et al., 2011; Streets et al., 2009), which may introduce uncertainties for our climate estimates. The simulations reflect a present-day climatology forced with recycled year 2010 anthropogenic emissions. Model-simulated $\mathrm{BC}$ concentrations were sampled in exact correspondence to the observed temporal period. In some limited cases, OA and AOD are not exactly temporally consistent with the available aerosol measurement network climatologies applied in the evaluation. For regions where carbonaceous aerosol emissions have undergone substantial changes over short periods in the past few years, the model-measurement compari- 
son may therefore introduce additional uncertainty. However, we focus the evaluation on the large-scale regional aerosol system dynamics. In the control simulation, the global annual mean $\mathrm{BC}$ burden and lifetime are $0.12 \pm 0.001 \mathrm{Tg}$ and $4.5 \pm 0.04$ days. For POM, the burden and lifetime are $0.66 \pm 0.006 \mathrm{Tg}$ and $4.8 \pm 0.04$ days. Annual mean surface BC (POM) concentrations over northern India, eastern China and sub-Saharan Africa are $1.55 \pm 0.076,0.76 \pm 0.028$ and $0.11 \pm 0.004 \mathrm{\mu g} \mathrm{m}^{-3} \quad(7.11 \pm 0.32, \quad 3.95 \pm 0.12$ and $0.48 \pm 0.02 \mu \mathrm{g} \mathrm{m}^{-3}$ ), respectively. BC and POM burdens from global solid fuel cookstove emissions are $0.029 \pm 0.001$ and $0.13 \pm 0.004 \mathrm{Tg}$, while contributions from the Indian sector are $0.006 \pm 0.000$ and $0.027 \pm 0.004 \mathrm{Tg}$, respectively.

In the default CESM simulations without treating $\mathrm{BC}$ as IN, globally averaged DRE values from global and Indian solid fuel cookstove emissions are $+70 \pm 3$ and $+11 \pm 1 \mathrm{~mW} \mathrm{~m}^{-2}$, respectively. The contributions of BC and POM from global solid fuel cookstove emissions to the DRE are $+105 \pm 4$ and $-14 \pm 1 \mathrm{~mW} \mathrm{~m}^{-2}$. Global annual mean SW and LW AIE values from global solid fuel cookstove emissions are $-122 \pm 22$ and $-104 \pm 17 \mathrm{~mW} \mathrm{~m}^{-2}$, with contributions from India yielding $-3 \pm 11 \mathrm{~mW} \mathrm{~m}^{-2}$ for the SW AIE and $-19 \pm 11 \mathrm{~mW} \mathrm{~m}^{-2}$ for the LW AIE, respectively. The cooling effect of the SW AIE is associated with the increases of $\mathrm{CCN}$ and $\mathrm{CDNC}$, whereas the negative effects of LW AIE are caused by the suppression of convection that transports water vapor from the lower troposphere to the UTLS, thus reducing ice cloud cover. The CAM5-Chem also computes the SAE, with global and Indian solid fuel cookstove emissions contributing $+15 \pm 3$ and $-2 \pm 3 \mathrm{~mW} \mathrm{~m}^{-2}$, respectively. As a result, the net total radiative effects of global and Indian solid fuel cookstove emissions are $-141 \pm 4$ and $-12 \pm 4 \mathrm{~mW} \mathrm{~m}^{-2}$, respectively, both producing a net cooling effect.

Sensitivity studies are carried out to examine the impacts of global and Indian solid fuel cookstove emissions on climate by treating $\mathrm{BC}$ as effective IN, with a MFE of 0.01 , 0.05 and 0.1 , respectively. For the radiative impacts of global solid fuel cookstove emissions, the global annual mean DRE is $+105 \pm 13 \mathrm{~mW} \mathrm{~m}^{-2}$, which is $\sim 50 \%$ higher than the default model scheme in which $\mathrm{BC}$ particles are not treated as IN (Fig. 6). This is driven by the increases of BC burden (due to prolonged BC lifetimes) from global solid fuel cookstove emissions by up to $17 \%$ with $\mathrm{BC}$ as IN. Because the $\mathrm{BC}$ absorption effect dominates the DRE, increases in $\mathrm{BC}$ burden enhance the magnitude of annual mean DRE (Jacobson, 2001a). Compared with the default model scheme, significant changes in globally averaged SW AIE are found, with a global annual mean of $-1.36 \pm 0.63 \mathrm{~W} \mathrm{~m}^{-2}$, which is about an order of magnitude higher than that from the default scheme. Moreover, in contrast to the cooling effect found in the default scheme, an annual mean positive LW AIE is simulated here $\left(+1.18 \pm 0.44 \mathrm{~W} \mathrm{~m}^{-2}\right)$. The above changes in cookstove-emission-induced SW and LW AIE are caused by the substantial increases in high cloud

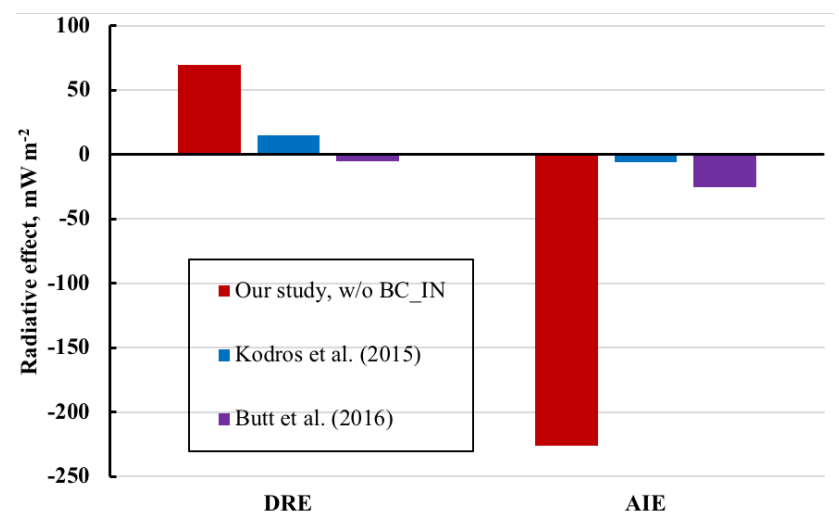

Figure 10. Comparisons of DRE (left) and AIE (right) radiative effects from global solid fuel cookstove emissions in our control simulation with Kodros et al. (2015) and Butt et al. (2016).

$(<500 \mathrm{hPa})$ fractions with $\mathrm{BC}$ particles acting as IN by up to $9 \%$ due to the effect of solid fuel cookstove emissions. Large increases in high cloud fractions are found mainly over tropical regions, especially over southern Africa. For the SAE, similar to the model default scheme, the global annual mean value is $+12 \pm 10 \mathrm{~mW} \mathrm{~m}^{-2}$. Summing the DRE, the AIE and the SAE, the net total radiative effect of global solid fuel cookstove emissions is $-59 \pm 215 \mathrm{~mW} \mathrm{~m}^{-2}$. For the Indian sector, the global mean total radiative effect is $0.3 \pm 29 \mathrm{~mW} \mathrm{~m}^{-2}$, with a net AIE $-18 \pm 37$ and a SAE of $+1 \pm 8 \mathrm{~mW} \mathrm{~m}^{-2}$, respectively.

We compare our simulation results with previous studies as shown in Fig. 10. The globally averaged DRE in our control simulation is more than 4 times higher than that from the baseline simulation of Kodros et al. (2015), which assumes a homogeneous particle mixing state (Fig. 10). Annual emissions of BC from global solid fuel cookstove sector in our study $\left(2.3 \mathrm{TgC} \mathrm{yr}^{-1}\right)$ is approximately $44 \%$ higher than that from the global biofuel emissions $\left(1.6 \mathrm{Tg} \mathrm{C} \mathrm{yr}^{-1}\right)$ in Kodros et al. (2015), which, to some extent, leads to differences in annual mean DRE values together with different optical calculations. The annual mean DRE value from another study by Butt et al. (2016) differs from ours in magnitude and sign, and concluded that the annually averaged DRE from residential combustion sources was $-5 \mathrm{~mW} \mathrm{~m}^{-2}$ (Fig. 10). The negative effect of DRE in Butt et al. (2016) is partially driven by the inclusion of $\mathrm{SO}_{2}$ emissions $(8.9 \mathrm{Tg}$ $\mathrm{SO}_{2} \mathrm{yr}^{-1}$ ) from commercial coal combustion in the residential sector, leading to the cooling effect of sulfate and organic aerosols outweighing the warming from BC. The AIE in our control simulation is 38 times higher than that from Kodros et al. (2015) and over an order of magnitude higher than that from Butt et al. (2016). Consistent with our study, Ward et al. (2012) also found a large AIE $\left(-1.74\right.$ to $\left.1.00 \mathrm{~W} \mathrm{~m}^{-2}\right)$ for carbonaceous aerosols from fires using CESM CAM4Chem. Both Kodros et al. (2015) and Butt et al. (2016) used offline radiative models to calculate AIE and only consid- 
ered the first (albedo) aerosol indirect effect, which may partially explain the AIE differences. As mentioned earlier, the AIE in our study includes aerosol first and second indirect effects as well as the semi-direct effect. Lacey and Henze (2015) estimated that the global surface air temperature changes due to solid wood fuel removal ranged from $-0.28 \mathrm{~K}$ (cooling) to $+0.16 \mathrm{~K}$ (warming), with a central estimate of $-0.06 \mathrm{~K}$ (cooling). This cooling estimate is opposite to our study. However, we acknowledge that there are fundamental differences in calculating the radiative effect between our study and Lacey and Henze (2015), which employed absolute regional temperature potentials to quantify the climate responses.

Cookstove intervention programs have been implemented in developing countries, such as China, India and some African countries, to improve air quality and human health and to mitigate climate change (Anenberg et al., 2017; Aung et al., 2016; Carter et al., 2016). Our results suggest that large-scale efforts to replace inefficient cookstoves in developing countries with advanced technologies is not likely to reduce global warming through aerosol reductions, and may even lead to increased global warming when aerosol-cloud interactions are taken into account. Therefore, without improved constraints on $\mathrm{BC}$ interactions with clouds, especially mixed-phase and ice clouds, the net sign of the impacts of carbonaceous aerosols from solid fuel cookstoves on global climate (warming or cooling) remains ambiguous. This study does not include the greenhouse gas emission effects from the solid fuel cookstove sector, which may indeed be large enough to imply a net warming global climate impact depending on timescale (Lacey et al., 2017).

Data availability. Data used in this study can be provided upon request to Nadine Unger (n.unger@ exeter.ac.uk), and Yaoxian Huang (yaoxian.huang1@gmail.com).

Competing interests. The authors declare that they have no conflict of interest.

Acknowledgements. This article was developed under Assistance Agreement No. R835421 awarded by the U.S. Environmental Protection Agency to SEI. It has not been formally reviewed by the EPA. The views expressed in this document are solely those of the authors and do not necessarily reflect those of the agency. The EPA does not endorse any products or commercial services mentioned in this publication. Nadine Unger acknowledges support from the University of Exeter, UK. The authors are grateful to Robert Bailis, Andrew Grieshop, Julian Marshall and Hisham Zerriffi for helpful discussions and conversations that guided the manuscript development. We are thankful for helpful discussions with Simone Tilmes and Steve Ghan. This project was supported in part by the facilities and staff of the Yale University High Performance Computing Center.
Edited by: James Allan

Reviewed by: two anonymous referees

\section{References}

Amann, M., Bertok, I., Borken-Kleefeld, J., Cofala, J., Heyes, C., Höglund-Isaksson, L., Klimont, Z., Nguyen, B., Posch, M., Rafaj, P., Sandler, R., Schöpp, W., Wagner, F., and Winiwarter, W.: Cost-effective control of air quality and greenhouse gases in Europe: Modeling and policy applications, Environ. Model. Softw., 26, 1489-1501, https://doi.org/10.1016/j.envsoft.2011.07.012, 2011.

Amann, M., Klimont, Z., and Wagner, F.: Regional and Global Emissions of Air Pollutants: Recent Trends and Future Scenarios, Annu. Rev. Environ. Resour., 38, 31-55, https://doi.org/10.1146/annurev-environ-052912-173303, 2013.

Anenberg, S. C., Henze, D. K., Lacey, F., Irfan, A., Kinney, P., Kleiman, G., and Pillarisetti, A.: Air pollution-related health and climate benefits of clean cookstove programs in Mozambique, Environ. Res. Lett., 12, 25006, https://doi.org/10.1088/17489326/aa5557, 2017.

Archer-Nicholls, S., Carter, E., Kumar, R., Xiao, Q., Liu, Y., Frostad, J., Forouzanfar, M. H., Cohen, A., Brauer, M., Baumgartner, J., and Wiedinmyer, C.: The regional impacts of cooking and heating emissions on ambient air quality and disease burden in China, Environ. Sci. Technol., 50, 9416-9423, https://doi.org/10.1021/acs.est.6b02533, 2016.

Aung, T. W., Jain, G., Sethuraman, K., Baumgartner, J., Reynolds, C., Grieshop, A. P., Marshall, J. D., and Brauer, M.: Health and Climate-Relevant Pollutant Concentrations from a Carbon-Finance Approved Cookstove Intervention in Rural India, Environ. Sci. Technol., 50, 7228-7238, https://doi.org/10.1021/acs.est.5b06208, 2016.

Barahona, D. and Nenes, A.: Parameterization of cirrus cloud formation in large-scale models: Homogeneous nucleation, J. Geophys. Res.-Atmos., 113, 1-15, https://doi.org/10.1029/2007JD009355, 2008.

Barahona, D. and Nenes, A.: Parameterizing the competition between homogeneous and heterogeneous freezing in ice cloud formation - polydisperse ice nuclei, Atmos. Chem. Phys., 9, 59335948, https://doi.org/10.5194/acp-9-5933-2009, 2009.

Bauer, S. E., Menon, S., Koch, D., Bond, T. C., and Tsigaridis, K.: A global modeling study on carbonaceous aerosol microphysical characteristics and radiative effects, Atmos. Chem. Phys., 10, 7439-7456, https://doi.org/10.5194/acp-10-7439-2010, 2010.

Bond, T., Venkataraman, C., and Masera, O.: Global atmospheric impacts of residential fuels, Energy Sustain. Dev., 8, 20-32, https://doi.org/10.1016/S0973-0826(08)60464-0, 2004.

Bond, T. C., Doherty, S. J., Fahey, D. W., Forster, P. M., Berntsen, T., Deangelo, B. J., Flanner, M. G., Ghan, S., Kärcher, B., Koch, D., Kinne, S., Kondo, Y., Quinn, P. K., Sarofim, M. C., Schultz, M. G., Schulz, M., Venkataraman, C., Zhang, H., Zhang, S., Bellouin, N., Guttikunda, S. K., Hopke, P. K., Jacobson, M. Z., Kaiser, J. W., Klimont, Z., Lohmann, U., Schwarz, J. P., Shindell, D., Storelvmo, T., Warren, S. G., and Zender, C. S.: Bounding the role of black carbon in the climate system: A sci- 
entific assessment, J. Geophys. Res.-Atmos., 118, 5380-5552, https://doi.org/10.1002/jgrd.50171, 2013.

Bonjour, S., Wolf, J., and Lahiff, M.: Solid Fuel Use for Household Cooking: Country and Regional Estimates for 1980-2010, Environ. Health Perspect., 121, 784-790, https://doi.org/10.1289/ehp.1205987, 2013.

Boucher, O., Randall, D., Artaxo, P., Bretherton, C., Feingold, G., Forster, P., Kerminen, V.-M., Kondo, Y., Liao, H., Lohmann, U., Rasch, P., Satheesh, S. K., Sherwood, S., Stevens, B., Zhang, X. Y., and Zhan, X. Y.: Clouds and Aerosols, Clim. Chang. 2013 Phys. Sci. Basis. Contrib. Work. Gr. I to Fifth Assess. Rep. Intergov. Panel Clim. Change, 571-657, https://doi.org/10.1017/CBO9781107415324.016, 2013.

Butt, E. W., Rap, A., Schmidt, A., Scott, C. E., Pringle, K. J., Reddington, C. L., Richards, N. A. D., Woodhouse, M. T., RamirezVillegas, J., Yang, H., Vakkari, V., Stone, E. A., Rupakheti, M., S. Praveen, P., G. van Zyl, P., P. Beukes, J., Josipovic, M., Mitchell, E. J. S., Sallu, S. M., Forster, P. M., and Spracklen, D. V.: The impact of residential combustion emissions on atmospheric aerosol, human health, and climate, Atmos. Chem. Phys., 16, 873-905, https://doi.org/10.5194/acp-16-873-2016, 2016.

Carter, E., Archer-Nicholls, S., Ni, K., Lai, A. M., Niu, H., Secrest, M. H., Sauer, S. M., Schauer, J. J., Ezzati, M., Wiedinmyer, C., Yang, X., and Baumgartner, J.: Seasonal and Diurnal Air Pollution from Residential Cooking and Space Heating in the Eastern Tibetan Plateau, Environ. Sci. Technol., 50, 8353-8361, https://doi.org/10.1021/acs.est.6b00082, 2016.

Chow, J. C., Watson, J. G., Pritchett, L. C., Pierson, W. R., Frazer, C. A., and Purcell, R. G.: The dri thermal/optical reflectance carbon analysis system: description, evaluation and applications in U.S. Air quality studies, Atmos. Environ., 27A, 1185-1201, 1993.

Chow, J. C., Watson, J. G., Chen, L.-W. A., Arnott, W. P., and Moosmuller, H.: Equivalence of Elemental Carbon by Thermal/Optical Reflectance and Transmittance with Different Temperature Protocols, Environ. Sci. Technol., 38, 4414-4422, 2004.

Chung, S. H.: Climate response of direct radiative forcing of anthropogenic black carbon, J. Geophys. Res., 110, D11102, https://doi.org/10.1029/2004JD005441, 2005.

Chung, S. H. and Seinfeld, J. H.: Global distribution and climate forcing of carbonaceous aerosols, J. Geophys. Res.-Atmos., 107, 4407, https://doi.org/10.1029/2001JD001397, 2002.

Chylek, P. and Wong, J.: Effect of absorbing aerosols on global radiation budget, Geophys. Res. Lett., 22, 929-931, 1995.

Cozic, J., Mertes, S., Verheggen, B., Cziczo, D. J., Gallavardin, S. J., Walter, S., Baltensperger, U., and Weingartner, E.: Black carbon enrichment in atmospheric ice particle residuals observed in lower tropospheric mixed phase clouds, J. Geophys. Res.-Atmos., 113, 1-11, https://doi.org/10.1029/2007JD009266, 2008.

DeMott, P. J., Chen, Y., Kreidenweis, S. M., Rogers, D. C., and Sherman, D. E.: Ice formation by black carbon particles, Geophys. Res. Lett., 26, 2429-2432, https://doi.org/10.1029/1999GL900580, 1999.

Dubovikl, O. and King, M. D.: A flexible inversion algorithm for retrieval of aerosol optical properties from Sun and sky radiance measurements, J. Geophys. Res., 105696, 673-20, https://doi.org/10.1029/2000JD900282, 2000.

EMEP/MSC-W, EMEP/CCC, EMEP/CEIP, IDAEA-CSIC, CCE/RIVM and FMI: Transboundary particulate matter, photo- oxidants, acidifying and eutrophying components, Norwegian Meteorological Institute, EMEP Report 1/2014, 216 pp., 2014.

Emmons, L. K., Walters, S., Hess, P. G., Lamarque, J.-F., Pfister, G. G., Fillmore, D., Granier, C., Guenther, A., Kinnison, D., Laepple, T., Orlando, J., Tie, X., Tyndall, G., Wiedinmyer, C., Baughcum, S. L., and Kloster, S.: Description and evaluation of the Model for Ozone and Related chemical Tracers, version 4 (MOZART-4), Geosci. Model Dev., 3, 43-67, https://doi.org/10.5194/gmd-3-43-2010, 2010.

Ezzati, M. and Kammen, D. M.: The health impacts of exposure to indoor air pollution from solid fuels in developing countries: Knowledge, gaps, and data needs, Environ. Health Perspect., 110, 1057-1068, https://doi.org/10.1289/ehp.021101057, 2002.

Fierce, L., Riemer, N., and Bond, T. C.: Toward reduced representation of mixing state for simulating aerosol effects on climate, B. Am. Meteorol. Soc., 98, 971-980, https://doi.org/10.1175/BAMS-D-16-0028.1, 2017.

Flanner, M. G., Zender, C. S., Randerson, J. T., and Rasch, P. J.: Present-day climate forcing and response from black carbon in snow, J. Geophys. Res.-Atmos., 112, 1-17, https://doi.org/10.1029/2006JD008003, 2007.

Gadhavi, H. S., Renuka, K., Ravi Kiran, V., Jayaraman, A., Stohl, A., Klimont, Z., and Beig, G.: Evaluation of black carbon emission inventories using a Lagrangian dispersion model - a case study over southern India, Atmos. Chem. Phys., 15, 1447-1461, https://doi.org/10.5194/acp-15-1447-2015, 2015.

Garland, C., Delapena, S., Prasad, R., L'Orange, C., Alexander, D., and Johnson, M.: Black carbon cookstove emissions: A field assessment of 19 stove/fuel combinations, Atmos. Environ., 169, 140-149, https://doi.org/10.1016/j.atmosenv.2017.08.040, 2017.

GBD 2015 Risk Factors Collaborators: Global, regional, and national comparative risk assessment of 79 behavioural, environmental and occupational, and metabolic risks or clusters of risks, 1990-2015: a systematic analysis for the Global Burden of Disease Study 2015, Lancet, 388, 1659-1724, https://doi.org/10.1016/S0140-6736(16)31679-8, 2016.

Gettelman, A., Liu, X., Barahona, D., Lohmann, U., and Chen, C.: Climate impacts of ice nucleation, J. Geophys. Res.-Atmos., 117, 1-14, https://doi.org/10.1029/2012JD017950, 2012.

Ghan, S. J.: Technical Note: Estimating aerosol effects on cloud radiative forcing, Atmos. Chem. Phys., 13, 9971-9974, https://doi.org/10.5194/acp-13-9971-2013, 2013.

Ghan, S. J., Liu, X., Easter, R. C., Zaveri, R., Rasch, P. J., Yoon, J. H., and Eaton, B.: Toward a minimal representation of aerosols in climate models: Comparative decomposition of aerosol direct, semidirect, and indirect radiative forcing, J. Climate, 25, 64616476, https://doi.org/10.1175/JCLI-D-11-00650.1, 2012.

Hanbar, R. D. and Karve, P.: National Programme on Improved Chulha (NPIC) of the Government of India: An overview, Energy Sustain. Dev., 6, 49-55, https://doi.org/10.1016/S09730826(08)60313-0, 2002.

He, C., Li, Q. B., Liou, K. N., Zhang, J., Qi, L., Mao, Y., Gao, M., Lu, Z., Streets, D. G., Zhang, Q., Sarin, M. M., and Ram, K.: A global 3-D CTM evaluation of black carbon in the Tibetan Plateau, Atmos. Chem. Phys., 14, 7091-7112, https://doi.org/10.5194/acp-14-7091-2014, 2014.

He, J. and Zhang, Y.: Improvement and further development in CESM/CAM5: gas-phase chemistry and inorganic 
aerosol treatments, Atmos. Chem. Phys., 14, 9171-9200, https://doi.org/10.5194/acp-14-9171-2014, 2014.

Holben, B. N., Eck, T. F., Slutsker, I., Tanré, D., Buis, J. P., Setzer, A., Vermote, E., Reagan, J. A., Kaufman, Y. J., Nakajima, T., Lavenu, F., Jankowiak, I., and Smirnov, A.: AERONET - A Federated Instrument Network and Data Archive for Aerosol Characterization, Remote Sens. Environ., 66, 1-16, https://doi.org/10.1016/S0034-4257(98)00031-5, 1998.

Holben, B. N., Tanré, D., Smirnov, A., Eck, T. F., Slutsker, I., Abuhassan, N., Newcomb, W. W., Schafer, J. S., Chatenet, B., Lavenu, F., Kaufman, Y. J., Castle, J. Vande, Setzer, A., Markham, B., Clark, D., Frouin, R., Halthore, R., Karneli, A., O'Neill, N. T., Pietras, C., Pinker, R. T., Voss, K., and Zibordi, G.: An emerging ground-based aerosol climatology: Aerosol optical depth from AERONET, J. Geophys. Res., 106, 12067, https://doi.org/10.1029/2001JD900014, 2001.

Huang, Y., Wu, S., Dubey, M. K., and French, N. H. F.: Impact of aging mechanism on model simulated carbonaceous aerosols, Atmos. Chem. Phys., 13, 6329-6343, https://doi.org/10.5194/acp13-6329-2013, 2013.

Jacobson, M. Z.: Global direct radiative forcing due to multicomponent natural and anthropoenic aerosols, J. Geophys. Res., 106, 1551-1568, https://doi.org/10.1029/2000JD900514, 2001a.

Jacobson, M. Z.: Strong radiative heating due to the mixing state of black carbon in atmospheric aerosols, Nature, 409, 695-697, https://doi.org/10.1038/35055518, 2001b.

Janssens-Maenhout, G., Crippa, M., Guizzardi, D., Dentener, F., Muntean, M., Pouliot, G., Keating, T., Zhang, Q., Kurokawa, J., Wankmüller, R., Denier van der Gon, H., Kuenen, J. J. P., Klimont, Z., Frost, G., Darras, S., Koffi, B., and Li, M.: HTAP_v2.2: a mosaic of regional and global emission grid maps for 2008 and 2010 to study hemispheric transport of air pollution, Atmos. Chem. Phys., 15, 11411-11432, https://doi.org/10.5194/acp-15-11411-2015, 2015.

Kanagawa, M. and Nakata, T.: Analysis of the energy access improvement and its socio-economic impacts in rural areas of developing countries, Ecol. Econ., 62, 319-329, https://doi.org/10.1016/j.ecolecon.2006.06.005, 2007.

Kärcher, B., Hendricks, J., and Lohmann, U.: Physically based parameterization of cirrus cloud formation for use in global atmospheric models, J. Geophys. Res., 111, D01205, https://doi.org/10.1029/2005JD006219, 2006.

Kishore, V. V. N. and Ramana, P. V.: Improved cookstoves in rural India: How improved are they? A critique of the perceived benefits from the National Programme on Improved Chulhas (NPIC), Energy, 27, 47-63, https://doi.org/10.1016/S03605442(01)00056-1, 2002.

Klimont, Z., Cofala, J., Wei, W., Zhang, C., Wang, S., Kejun, J., Bhandari, P., Mathur, R., Purohit, P., Rafaj, P., Chambers, A., Amann, M., and $\mathrm{Hao}$, J.: Projections of $\mathrm{SO}_{2}, \mathrm{NO}_{x}$ and carbonaceous aerosols emissions in Asia, Tellus, Ser. B Chem. Phys. Meteorol., 61B, 602-617, https://doi.org/10.1111/j.16000889.2009.00428.x, 2009.

Klimont, Z., Kupiainen, K., Heyes, C., Purohit, P., Cofala, J., Rafaj, P., Borken-Kleefeld, J., and Schöpp, W.: Global anthropogenic emissions of particulate matter including black carbon, Atmos. Chem. Phys., 17, 8681-8723, https://doi.org/10.5194/acp-178681-2017, 2017.
Kodros, J. K., Scott, C. E., Farina, S. C., Lee, Y. H., L'Orange, C., Volckens, J., and Pierce, J. R.: Uncertainties in global aerosols and climate effects due to biofuel emissions, Atmos. Chem. Phys., 15, 8577-8596, https://doi.org/10.5194/acp-158577-2015, 2015.

Koehler, K. A., DeMott, P. J., Kreidenweis, S. M., Popovicheva, O. B., Petters, M. D., Carrico, C. M., Kireeva, E. D., Khokhlova, T. D., and Shonija, N. K.: Cloud condensation nuclei and ice nucleation activity of hydrophobic and hydrophilic soot particles, Phys. Chem. Chem. Phys., 11, 79067920, https://doi.org/10.1039/b916865f, 2009.

Kooperman, G. J., Pritchard, M. S., Ghan, S. J., Wang, M., Somerville, R. C. J., and Russell, L. M.: Constraining the influence of natural variability to improve estimates of global aerosol indirect effects in a nudged version of the Community Atmosphere Model 5, J. Geophys. Res.-Atmos., 117, 1-16, https://doi.org/10.1029/2012JD018588, 2012.

Kulkarni, G., China, S., Liu, S., Nandasiri, M., Sharma, N., Wilson, J., Aiken, A. C., Chand, D., Laskin, A., Mazzoleni, C., Pekour, M., Shilling, J., Shutthanandan, V., Zelenyuk, A., and Zaveri, R. A.: Ice nucleation activity of diesel soot particles at cirrus relevant temperature conditions: Effects of hydration, secondary organics coating, soot morphology, and coagulation, Geophys. Res. Lett., 43, 3580-3588, https://doi.org/10.1002/2016GL068707, 2016.

Lacey, F. and Henze, D.: Global climate impacts of countrylevel primary carbonaceous aerosol from solid-fuel cookstove emissions, Environ. Res. Lett., 10, 114003, https://doi.org/10.1088/1748-9326/10/11/114003, 2015.

Lacey, F. G., Henze, D. K., Lee, C. J., van Donkelaar, A., and Martin, R. V.: Transient climate and ambient health impacts due to national solid fuel cookstove emissions, P. Natl. Acad. Sci. USA, 114, 1269-1274, https://doi.org/10.1073/pnas.1612430114, 2017.

Lamarque, J.-F., Emmons, L. K., Hess, P. G., Kinnison, D. E., Tilmes, S., Vitt, F., Heald, C. L., Holland, E. A., Lauritzen, P. H., Neu, J., Orlando, J. J., Rasch, P. J., and Tyndall, G. K.: CAM-chem: description and evaluation of interactive atmospheric chemistry in the Community Earth System Model, Geosci. Model Dev., 5, 369-411, https://doi.org/10.5194/gmd-5369-2012, 2012.

Legros, G., Havet, I., Bruce, N., and Bonjour, S.: The Energy Access Situation in Developing Countries, WHO UNDP, 142, available at: http://scholar.google.com/scholar?hl=en\&btnG=Search\&q= intitle:THE+ENERGY+ACCESS+SITUATION+IN +DEVELOPING+COUNTRIES+A+Review+Focusing+on+the\#0, 2009.

Lelieveld, J., Evans, J. S., Fnais, M., Giannadaki, D., and Pozzer, A.: The contribution of outdoor air pollution sources to premature mortality on a global scale, Nature, 525, 367-371, https://doi.org/10.1038/nature15371, 2015.

Liu, J., Mauzerall, D. L., Chen, Q., Zhang, Q., Song, Y., Peng, W., Klimont, Z., Qiu, X., Zhang, S., Hu, M., Lin, W., Smith, K. R., and Zhu, T.: Air pollutant emissions from Chinese households: A major and underappreciated ambient pollution source, P. Natl. Acad. Sci. USA, 113, 7756-7761, https://doi.org/10.1073/pnas.1604537113, 2016. 
Liu, X. and Penner, J. E.: Ice nucleation parameterization for global models, Meteorol. Z., 14, 499-514, https://doi.org/10.1127/0941-2948/2005/0059, 2005.

Liu, X., Penner, J. E., Ghan, S. J., and Wang, M.: Inclusion of ice microphysics in the NCAR Community Atmospheric Model version 3 (CAM3), J. Climate, 20, 4526-4547, https://doi.org/10.1175/JCLI4264.1, 2007.

Liu, X., Easter, R. C., Ghan, S. J., Zaveri, R., Rasch, P., Shi, X., Lamarque, J.-F., Gettelman, A., Morrison, H., Vitt, F., Conley, A., Park, S., Neale, R., Hannay, C., Ekman, A. M. L., Hess, P., Mahowald, N., Collins, W., Iacono, M. J., Bretherton, C. S., Flanner, M. G., and Mitchell, D.: Toward a minimal representation of aerosols in climate models: description and evaluation in the Community Atmosphere Model CAM5, Geosci. Model Dev., 5, 709-739, https://doi.org/10.5194/gmd-5-709-2012, 2012.

Lohmann, U.: A glaciation indirect aerosol effect caused by soot aerosols, Geophys. Res. Lett., 29, 1052, https://doi.org/10.1029/2001g1014357, 2002.

Lohmann, U., Feichter, J., Penner, J., and Leaitch, R.: Indirect effect of sulfate and carbonaceous aerosols: A mechanistic treatment, J. Geophys. Res.-Atmos., 105, 12193-12206, https://doi.org/10.1029/1999JD901199, 2000.

Lu, Z., Zhang, Q., and Streets, D. G.: Sulfur dioxide and primary carbonaceous aerosol emissions in China and India, 1996-2010, Atmos. Chem. Phys., 11, 9839-9864, https://doi.org/10.5194/acp-11-9839-2011, 2011.

Malm, W. C., Sisler, J. F., Huffman, D., Eldred, R. A., and Cahill, T. A.: Spatial and seasonal trends in particle concentration and optical extinction in the United States, J. Geophys. Res., 99, 13471370, https://doi.org/10.1029/93JD02916, 1994.

Myhre, G., Samset, B. H., Schulz, M., Balkanski, Y., Bauer, S., Berntsen, T. K., Bian, H., Bellouin, N., Chin, M., Diehl, T., Easter, R. C., Feichter, J., Ghan, S. J., Hauglustaine, D., Iversen, T., Kinne, S., Kirkevåg, A., Lamarque, J.-F., Lin, G., Liu, X., Lund, M. T., Luo, G., Ma, X., van Noije, T., Penner, J. E., Rasch, P. J., Ruiz, A., Seland, Ø., Skeie, R. B., Stier, P., Takemura, T., Tsigaridis, K., Wang, P., Wang, Z., Xu, L., Yu, H., Yu, F., Yoon, J.-H., Zhang, K., Zhang, H., and Zhou, C.: Radiative forcing of the direct aerosol effect from AeroCom Phase II simulations, Atmos. Chem. Phys., 13, 1853-1877, https://doi.org/10.5194/acp13-1853-2013, 2013.

Pan, X., Chin, M., Gautam, R., Bian, H., Kim, D., Colarco, P. R., Diehl, T. L., Takemura, T., Pozzoli, L., Tsigaridis, K., Bauer, S., and Bellouin, N.: A multi-model evaluation of aerosols over South Asia: common problems and possible causes, Atmos. Chem. Phys., 15, 5903-5928, https://doi.org/10.5194/acp15-5903-2015, 2015.

Penner, J. E., Dickinson, R. E., and O'Neill, C. A.: Effects of Aerosol from Biomass Burning on the Global Radiation Budget, Science, 256, 1432-1435, https://doi.org/10.1126/science.256.5062.1432, 1992.

Penner, J. E., Chen, Y., Wang, M., and Liu, X.: Possible influence of anthropogenic aerosols on cirrus clouds and anthropogenic forcing, Atmos. Chem. Phys., 9, 879-896, https://doi.org/10.5194/acp-9-879-2009, 2009.

Pierce, J. R., Chen, K., and Adams, P. J.: Contribution of primary carbonaceous aerosol to cloud condensation nuclei: processes and uncertainties evaluated with a global aerosol microphysics model, Atmos. Chem. Phys., 7, 5447-5466, https://doi.org/10.5194/acp-7-5447-2007, 2007.

Quennehen, B., Raut, J.-C., Law, K. S., Daskalakis, N., Ancellet, G., Clerbaux, C., Kim, S.-W., Lund, M. T., Myhre, G., Olivié, D. J. L., Safieddine, S., Skeie, R. B., Thomas, J. L., Tsyro, S., Bazureau, A., Bellouin, N., Hu, M., Kanakidou, M., Klimont, Z., Kupiainen, K., Myriokefalitakis, S., Quaas, J., Rumbold, S. T., Schulz, M., Cherian, R., Shimizu, A., Wang, J., Yoon, S.-C., and Zhu, T.: Multi-model evaluation of short-lived pollutant distributions over east Asia during summer 2008, Atmos. Chem. Phys., 16, 10765-10792, https://doi.org/10.5194/acp-16-107652016, 2016.

Reddington, C. L., Spracklen, D. V., Artaxo, P., Ridley, D. A., Rizzo, L. V., and Arana, A.: Analysis of particulate emissions from tropical biomass burning using a global aerosol model and long-term surface observations, Atmos. Chem. Phys., 16, 1108311106, https://doi.org/10.5194/acp-16-11083-2016, 2016.

Riahi, K., Rao, S., Krey, V., Cho, C., Chirkov, V., Fischer, G., Kindermann, G., Nakicenovic, N., and Rafaj, P.: RCP 8.5-A scenario of comparatively high greenhouse gas emissions, Clim. Change, 109, 33-57, https://doi.org/10.1007/s10584-011-0149-y, 2011.

Schulz, M., Textor, C., Kinne, S., Balkanski, Y., Bauer, S., Berntsen, T., Berglen, T., Boucher, O., Dentener, F., Guibert, S., Isaksen, I. S. A., Iversen, T., Koch, D., Kirkevåg, A., Liu, X., Montanaro, V., Myhre, G., Penner, J. E., Pitari, G., Reddy, S., Seland, Ø., Stier, P., and Takemura, T.: Radiative forcing by aerosols as derived from the AeroCom present-day and pre-industrial simulations, Atmos. Chem. Phys., 6, 5225-5246, https://doi.org/10.5194/acp6-5225-2006, 2006.

Smith, K. R., Bruce, N., Balakrishnan, K., Adair-Rohani, H., Balmes, J., Chafe, Z., Dherani, M., Hosgood, H. D., Mehta, S., Pope, D., and Rehfuess, E.: Millions Dead: How Do We Know and What Does It Mean? Methods Used in the Comparative Risk Assessment of Household Air Pollution, Annu. Rev. Public Health, 35, 185-206, https://doi.org/10.1146/annurevpublhealth-032013-182356, 2014.

Spracklen, D. V., Jimenez, J. L., Carslaw, K. S., Worsnop, D. R., Evans, M. J., Mann, G. W., Zhang, Q., Canagaratna, M. R., Allan, J., Coe, H., McFiggans, G., Rap, A., and Forster, P.: Aerosol mass spectrometer constraint on the global secondary organic aerosol budget, Atmos. Chem. Phys., 11, 12109-12136, https://doi.org/10.5194/acp-11-12109-2011, 2011a.

Spracklen, D. V., Carslaw, K. S., Pöschl, U., Rap, A., and Forster, P. M.: Global cloud condensation nuclei influenced by carbonaceous combustion aerosol, Atmos. Chem. Phys., 11, 9067-9087, https://doi.org/10.5194/acp-11-9067-2011, 2011 b.

Stohl, A., Aamaas, B., Amann, M., Baker, L. H., Bellouin, N., Berntsen, T. K., Boucher, O., Cherian, R., Collins, W., Daskalakis, N., Dusinska, M., Eckhardt, S., Fuglestvedt, J. S., Harju, M., Heyes, C., Hodnebrog, Ø., Hao, J., Im, U., Kanakidou, M., Klimont, Z., Kupiainen, K., Law, K. S., Lund, M. T., Maas, R., MacIntosh, C. R., Myhre, G., Myriokefalitakis, S., Olivié, D., Quaas, J., Quennehen, B., Raut, J.-C., Rumbold, S. T., Samset, B. H., Schulz, M., Seland, Ø., Shine, K. P., Skeie, R. B., Wang, S., Yttri, K. E., and Zhu, T.: Evaluating the climate and air quality impacts of short-lived pollutants, Atmos. Chem. Phys., 15, 10529-10566, https://doi.org/10.5194/acp-15-105292015, 2015. 
Streets, D. G., Yan, F., Chin, M., Diehl, T., Mahowald, N., Schultz, M., Wild, M., Wu, Y., and Yu, C.: Anthropogenic and natural contributions to regional trends in aerosol optical depth, 1980-2006, J. Geophys. Res.-Atmos., 114, 1-16, https://doi.org/10.1029/2008JD011624, 2009.

Textor, C., Schulz, M., Guibert, S., Kinne, S., Balkanski, Y., Bauer, S., Berntsen, T., Berglen, T., Boucher, O., Chin, M., Dentener, F., Diehl, T., Easter, R., Feichter, H., Fillmore, D., Ghan, S., Ginoux, P., Gong, S., Grini, A., Hendricks, J., Horowitz, L., Huang, P., Isaksen, I., Iversen, I., Kloster, S., Koch, D., Kirkevåg, A., Kristjansson, J. E., Krol, M., Lauer, A., Lamarque, J. F., Liu, X., Montanaro, V., Myhre, G., Penner, J., Pitari, G., Reddy, S., Seland, Ø., Stier, P., Takemura, T., and Tie, X.: Analysis and quantification of the diversities of aerosol life cycles within AeroCom, Atmos. Chem. Phys., 6, 1777-1813, https://doi.org/10.5194/acp-6-17772006, 2006.

Tilmes, S., Lamarque, J.-F., Emmons, L. K., Kinnison, D. E., Ma, P.-L., Liu, X., Ghan, S., Bardeen, C., Arnold, S., Deeter, M., Vitt, F., Ryerson, T., Elkins, J. W., Moore, F., Spackman, J. R., and Val Martin, M.: Description and evaluation of tropospheric chemistry and aerosols in the Community Earth System Model (CESM1.2), Geosci. Model Dev., 8, 1395-1426, https://doi.org/10.5194/gmd8-1395-2015, 2015.

Venkataraman, C., Habib, G., Eiguren-Fernandez, A., Miguel, A. H., and Friendlander, S. K.: Residential Biofuels in South Asia: Carbonaceous Aerosol Emissions and Climate Impacts, Science, 307, 1454-1456, https://doi.org/10.1126/science.1104359, 2005.

Venkataraman, C., Sagar, A. D., Habib, G., Lam, N., and Smith, K. R.: The Indian National Initiative for Advanced Biomass Cookstoves: The benefits of clean combustion, Energy Sustain. Dev., 14, 63-72, https://doi.org/10.1016/j.esd.2010.04.005, 2010.

Wang, Q., Jacob, D. J., Fisher, J. A., Mao, J., Leibensperger, E. M., Carouge, C. C., Le Sager, P., Kondo, Y., Jimenez, J. L., Cubison, M. J., and Doherty, S. J.: Sources of carbonaceous aerosols and deposited black carbon in the Arctic in winter-spring: implications for radiative forcing, Atmos. Chem. Phys., 11, 1245312473, https://doi.org/10.5194/acp-11-12453-2011, 2011.

Wang, Q., Jacob, D. J., Spackman, J. R., Perring, A. E., Schwarz, J. P., Moteki, N., Marais, E. A., Ge, C., Wang, J., and Barrett, S. R. H.: Global budget and radiative forcing of black carbon aerosol: Constraints from pole-to-pole (HIPPO) observations across the Pacific, J. Geophys. Res., 119, 195-206, https://doi.org/10.1002/2013JD020824, 2014a.
Wang, X., Heald, C. L., Ridley, D. A., Schwarz, J. P., Spackman, J. R., Perring, A. E., Coe, H., Liu, D., and Clarke, A. D.: Exploiting simultaneous observational constraints on mass and absorption to estimate the global direct radiative forcing of black carbon and brown carbon, Atmos. Chem. Phys., 14, 10989-11010, https://doi.org/10.5194/acp-14-10989-2014, 2014b.

Ward, D. S., Kloster, S., Mahowald, N. M., Rogers, B. M., Randerson, J. T., and Hess, P. G.: The changing radiative forcing of fires: global model estimates for past, present and future, Atmos. Chem. Phys., 12, 10857-10886, https://doi.org/10.5194/acp-1210857-2012, 2012.

Zhang, L., Henze, D. K., Grell, G. A., Carmichael, G. R., Bousserez, N., Zhang, Q., Torres, O., Ahn, C., Lu, Z., Cao, J., and Mao, Y.: Constraining black carbon aerosol over Asia using OMI aerosol absorption optical depth and the adjoint of GEOS-Chem, Atmos. Chem. Phys., 15, 10281-10308, https://doi.org/10.5194/acp-1510281-2015, 2015.

Zhang, Q., Jimenez, J. L., Canagaratna, M. R., Allan, J. D., Coe, H., Ulbrich, I., Alfarra, M. R., Takami, A., Middlebrook, A. M., Sun, Y. L., Dzepina, K., Dunlea, E., Docherty, K., DeCarlo, P. F., Salcedo, D., Onasch, T., Jayne, J. T., Miyoshi, T., Shimono, A., Hatakeyama, S., Takegawa, N., Kondo, Y., Schneider, J., Drewnick, F., Borrmann, S., Weimer, S., Demerjian, K., Williams, P., Bower, K., Bahreini, R., Cottrell, L., Griffin, R. J., Rautiainen, J., Sun, J. Y., Zhang, Y. M., and Worsnop, D. R.: Ubiquity and dominance of oxygenated species in organic aerosols in anthropogenically-influenced Northern Hemisphere midlatitudes, Geophys. Res. Lett., 34, 1-6, https://doi.org/10.1029/2007GL029979, 2007.

Zheng, Y., Unger, N., Hodzic, A., Emmons, L., Knote, C., Tilmes, S., Lamarque, J.-F., and Yu, P.: Limited effect of anthropogenic nitrogen oxides on secondary organic aerosol formation, Atmos. Chem. Phys., 15, 13487-13506, https://doi.org/10.5194/acp-1513487-2015, 2015. 